\title{
Diagnosis of Chagas' cardiomyopathy. Non-invasive techniques
}

\author{
JuAN José Puigbó \\ M.D. \\ EDUARDO HiRSCHHAUT \\ M.D. \\ ITALO BOCCALANDRO \\ M.D.
}

\author{
RAFAel VALECILlos* \\ M.D.
}

Hugo Giordano M.*

M.D.

Claudia Suárez $\dagger$

M.D.

\begin{abstract}
Summary
The natural history of Chagas' disease and its manifestations when the heart is involved are detailed clinically and pathologically. Three phases are recognized: the acute phase, lasting from 1-3 months, the latent phase, which may last from 10-20 years, and the chronic phase, which has the most serious manifestations. This phase is subdivided into three clinical stages. An analysis of the varied cardiac manifestations on 235 patients is included.
\end{abstract}

\section{Introduction}

Chagas' disease represents a serious problem to public health. It affects large rural areas in Latin America and is associated with a high rate of mortality. Individuals are usually affected at the peak of their productive lives. The rate of infection by Trypanosoma cruzi as shown by complement fixation tests is high, reaching $40-50 \%$ of the population in the affected areas. The rate of chronic Chagas' disease is also high (around 15\% in those areas which have been studied) (Laranja et al., 1956; Pifano, Romero and Domf́nguez, 1965; Puigbó et al., 1966; Puigbó, 1968).

\section{Natural history}

Acute phase

Of all the visceral pathology which can occur in this phase (as well as the chronic phase) it is the attack on the myocardium which manifests itself clinically.

The progress may be summarized as follows:

The acute phase lasts for 1 to 3 months following an incubation period of 1 to 3 weeks, and usually occurs during the first decade of life. The main clinical manifestations include: signs of local invasion by the parasite including the ophthalmicganglionic complex (Romana sign), inoculation chagoma and general symptoms related to systemic invasion by the parasite, such as fever, hepatosplenomegaly, lymphadenopathy, oedema and signs and symptoms of acute Chagasic cardiomyopathy. In the heart, the myocardial fibres are the site of predilection for the parasite and it is there that reproduction occurs. The severity of myocardial involvement varies widely and it may even be clinically silent. It may be so severe as to lead to the patient's death. The severe forms are rarer and account for $3-10 \%$ of cases.

The cardiovascular signs consist of tachycardia, which is usually greater than can be accounted for by the level of fever, arterial hypotension and low pulse pressure. Alteration of the heart sounds, particularly a soft first sound, or equal intensity of both sounds, gallop rhythm and varying degrees of cardiomegaly, are encountered. Evidence of congestive heart failure may be found if the cardiac involvement has been severe. Electrocardiographic disturbances include prolongation of the PR and QT intervals and non-specific alterations of the $T$ wave and the ST segment. Low voltage $Q R S$ complexes are occasionally encountered. Experience has shown that in the majority of cases the cardiovascular signs may either be completely or partially reversed.

The most characteristic laboratory findings are leucocytosis and lymphocytosis and presence of the parasite in the blood. The complement fixation test becomes positive from 15 to 30 days after the onset of infection. 
Pathological examination shows that the myocardium is the organ most commonly involved. Histologically a severe myocarditis with an interstitial cellular infiltrate consisting predominantly of polymorphonuclear neutrophils is seen. In the acute phase the presence of parasites within the myocardial fibres, the so-called pseudo-Leishmanic cysts, are characteristic. In some areas degeneration of the myocardium and early fibrosis may be found.

\section{Latent phase}

This is the period which follows the cessation of the acute phase and lasts to the beginning of the chronic phase. The complement fixation tests remain positive. Little is known of the anatomico-pathological lesions. It is estimated that this phase lasts from 10 to 20 years.

\section{Chronic phase: chronic Chagasic cardiomyopathy}

This is the most important phase, and constitutes the most serious problem, both medically and socially. The patients are usually between 15 and 50 years of age (Puigbó et al., 1966; Puigbó, 1968) with a peak incidence in the third decade. All these patients have lived in endemic areas, usually in palm-thatched dwellings, and frequently remember stings by the vector insect (haematophagous reduviids). The complement fixation tests are positive. Frequently, the acute and latent phases cannot be ascertained, and chronic cardiomyopathy may be the first manifestation. Xenodiagnosis is positive in approximately one third of the chronic cases.

The clinical manifestation of chronic Chagas' disease may be divided into three stages (Puigbó et al., 1968a).

\section{First stage}

In the early stage the patients may be without symptoms or may just have rhythm disturbances, dizziness and fainting spells. On examination extrasystoles and splitting of the second sound may be found. At this stage cardiomegaly or cardiac failure is not evident. The chest X-ray is usually normal. Segmental hypokinesis may, however, occasionally be found on fluoroscopic examination.

Electro- and vectorcardiograms show signs of myocardial involvement including right bundle branch block, extensive and accentuated disturbances of ventricular repolarization and multifocal extrasystoles. These changes may occur in isolation or in combination. Left anterior hemiblock (Rosenbaum, Elizari and Lazzari, 1968) is not usually found. Vector cardiography confirms the electrocardiographic findings and also does not show marked displacement of the QRS loop (Pileggi, Ebaid and Tranchesi, 1961).

Cardiac catheterization. Haemodynamic data, blood gases, and arterial pressure response to the Valsalva manoeuvre at rest or on effort, are within normal limits. Right and left intracardiac and intravascular pressures are within normal limits (Puigbó et al., 1968b).

Ventriculography. This is useful and often slight dilatation of the ventricular cavities associated with hypokinesis is found.

Pathology. Macroscopically, characteristic circumscribed apical thinning, usually without thrombosis (Mignone, 1958) is present. The ventricles are conical in shape and slightly dilated. Hypertrophy of the left ventricular wall proximal to the apical lesion is a striking finding.

Histologically, interstitial cellular infiltration, consisting predominantly of mononuclear cells, is seen. Myocardial fibrosis, particularly in the inner layers of the ventricular wall, and myocytolysis are found.

Causes of death at this stage are usually cardiac dysrhythmias.

\section{Second stage}

Symptoms may still be slight, and moderate cardiomegaly is found. Fluoroscopy may often show paradoxical movement.

New electro- and vectorcardiographic signs mat appear, reflecting myocardial damage. Left anterio hemiblock and electrically inactive zones are en countered, as well as upper displacement and dee. formity of the QRS loop.

Cardiac catheterization shows similar changes to those found in the first stage, but ventriculographic findings are more severe (Puigbó et al., 1968b).

Causes of death. Sudden death is usual.

\section{Third stage}

Clinically, marked cardiomegaly and congestive cardiac failure with mitral and/or tricuspid insufficiency, thromboembolic phenomena and complex and severe arrhythmias are characteristic of this stage.

X-ray studies confirm the extreme cardiomegaly, and electro- and vectorcardiography now show extensive electrically inactive zones.

Cardiac catheterization confirms a low cardiac output and valvar insufficiency. Pulmonary hypertension may be slight or moderate.

Ventriculography shows hypokinesia with severe pulmonary cone dilatation.

Pathologically, the apical lesion is extensive and $\tilde{O}$ accompanied by mural thrombosis. Hypertrophy స్ and severe dilatation of all cavities in the heart are found.

Histologically, extensive myocytolysis and fibrosis $\frac{0}{\mathbb{D}}$ is found, but only very rarely are parasites found $\stackrel{\oplus}{+}$ within cardiac fibres. 
Causes of death are heart failure and thromboembolic phenomena.

It should be remembered that at any stage of the disease complete A-V block with Stokes-Adams

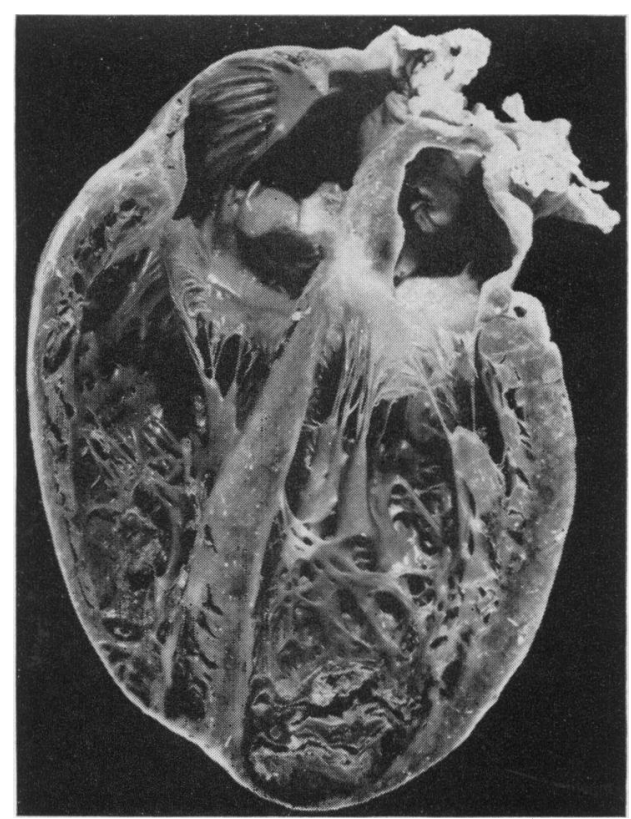

FIG. 1. The heart has been dissected to show both atrial and ventricular cavities. Note the thinning of the left ventricular wall in the apical region. That area is also filled with thrombus. attacks may occur, and the risk of dying is present throughout the course of Chagas' disease.

The following is an analysis of the findings in a total of 235 patients (Boccalandro and Hirschhaut, 1974).

\section{Electro- and vectorcardiographic findings}

These are often the earliest changes. The findings were as follows: disturbances of ventricular repolarization $58 \%$; right bundle branch block $55 \%$; left bundle branch block $4 \%$; left anterior hemiblock $30 \%$. In 45 patients an increase of ventricular potentials was encountered and in $10 \%$ a diffuse decrease in voltage complexes was seen.

Frequent ventricular ectopic beats were found in $28 \%$, and sinus bradycardia in $11 \%$ of patients. Atrioventricular block was found in $10 \%$.

Electrically inactive zones were observed in $27 \%$, which were mainly located in the inferior aspects of the left ventricle.

Deformed $P$ waves were found in $14 \%$ and deformed QRS loops in the vectorcardiogram in $15 \%$ of patients. These anomalies correlated well with the localization and severity of the pathological lesions and formed a useful diagnostic outline in the followup of patients. Furthermore, the vectorcardiogram helps to localize and reveal extensions of inactive zones.

\section{Effort electrocardiography}

Effort electrocardiography (Hirschhaut, 1967, 1972; Hirschhaut, Aparicio and Beer, 1975) has also

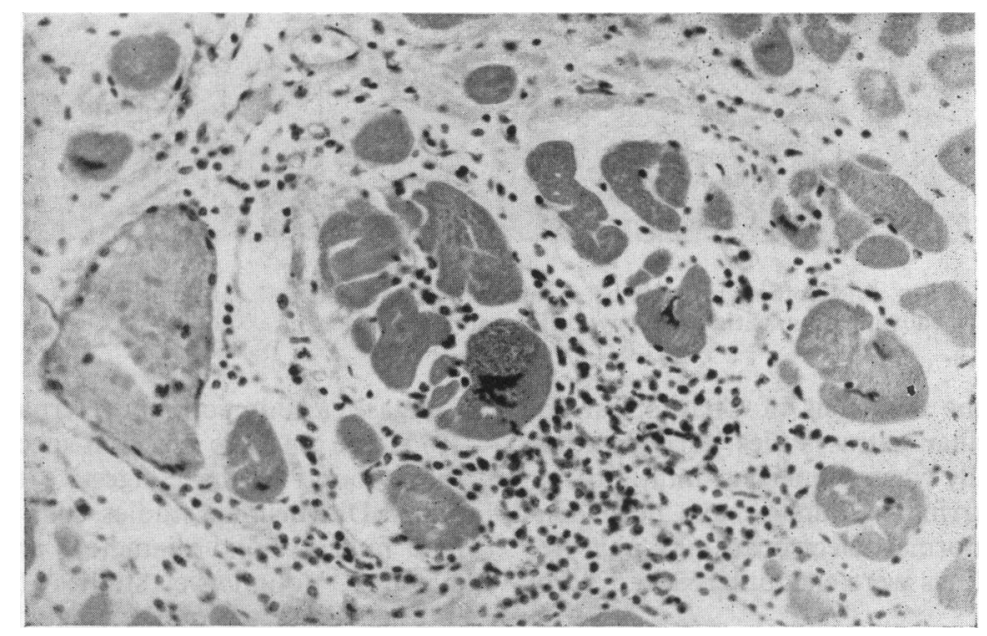

FIg. 2. Photomicrograph of the myocardium in chronic Chagas' disease. Note in the centre a hypertrophied myocardial cell showing numerous small bodies, Trypanosoma cruzi. A moderately severe chronic inflammatory infiltrate is also present in the surrounding tissue. Haematoxylin and eosin $\times 400$. 


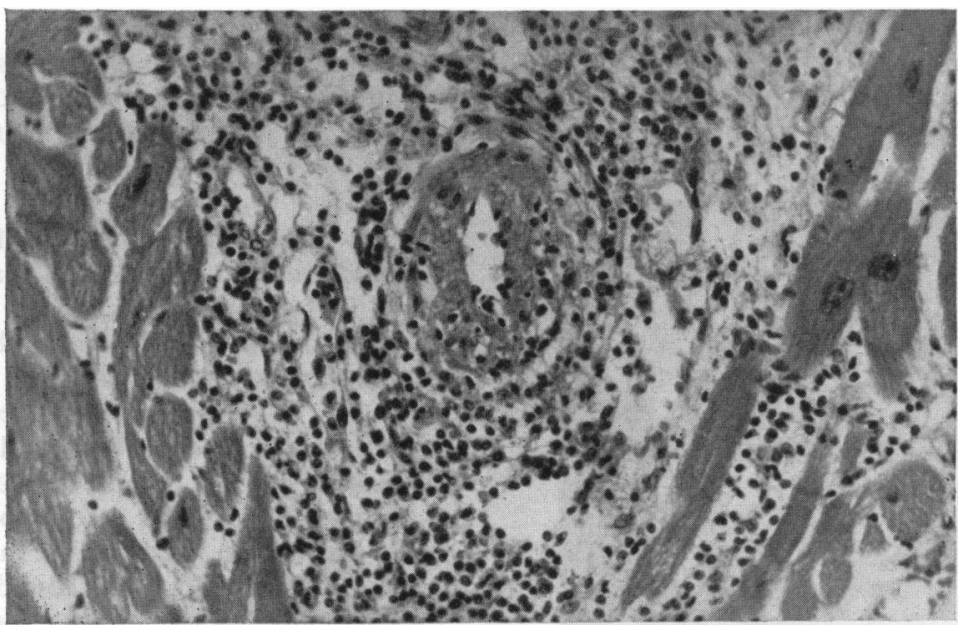

FIG. 3. Photomicrograph of a patient with chronic Chagas' cardiomyopathy, showing an inflammatory infiltrate involving an arteriole in the myocardium. Haematoxylin and eosin $\times 400$.

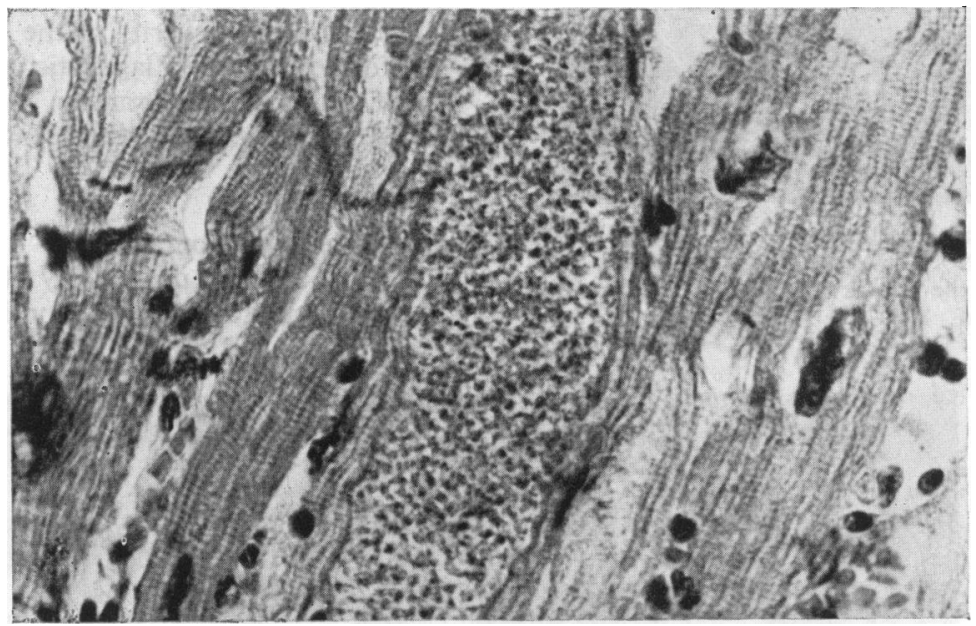

FIg. 4. Photomicrograph of a case with acute Chagas' cardiomyopathy, showing a parasitic pseudocyst. Haematoxylin and eosin $\times 720$.

proved of use in the diagnosis of Chagas' cardiomyopathy. Ventricular extrasystoles during and/or after effort, especially when numerous, multifocal or bigeminal, or occurring in bursts, have been considered to be abnormal electrocardiographic responses. These findings were encountered in $52 \%$ of patients.

\section{Echocardiography}

Echocardiographic investigation has been found useful in the differentiation of the various forms of cardiomyopathies (Zoneraich, 1974). In chronic
Chagas' cardiomyopathy (Hernández-Pieretti et al., 을 1975) the findings are non-specific and similar to those found in the congestive type of cardiomyopathy. Dimensional studies, such as the final diastolic and final systolic diameter, are increased above $\sigma$ average. Volumetric studies (derived from the $\mathbb{N}$ internal diameter of the final diastolic ventricular $N_{\mathcal{E}}$ volume, final systolic stroke volume and ejection fraction) can be used, but these and other similar 0 studies are not reliable, owing to the extensive $\frac{\mathbb{D}}{}$ dyskinesia which may be present.

The dimensions of the left ventricular outflow 0 
tract at the beginning of ventricular systole (between point $\mathrm{C}$ of mitral valve closure and left septal surface) has also proved of value in the assessment of the different forms of cardiomyopathy. Chronic Chagas' disease resembles congestive cardiomyopathy and values of up to $50 \mathrm{~mm}$ are frequently found (N 20-34 mm).

Left atrial and right ventricular dimensions are also usually above normal values.

Regarding mitral valve movements, a decrease in amplitude (N $20 \mathrm{~mm}$ ) of points $\mathrm{C}$ and $\mathrm{E}$ are found, as in other patients with low cardiac output. Changes of severe dilatation are also seen (HernándezPieretti et al., 1975; Joyner, 1974).

A normal E-F loop is frequently found in chronic Chagas' cardiomyopathy and helps to differentiate it from hypertrophic obstructive cardiomyopathy and non-obstructive cardiomyopathy.

Alterations in the aortic echocardiogram, consisting of loss of normal parallelism, are encountered. A decrease in the amplitude of septal movement when present, represents a fairly early change, and a decrease in the speed of posterior wall movement represents more severe changes of ventricular function.

In these studies the authors have found that echocardiography may be of great help in the study of chronic Chagas' cardiomyopathy, for it allows them to assess myocardial damage and helps to distinguish patients with trypanosomal infection with or without cardiac involvement, and also helps in the follow-up of patients with chronic Chagas' cardiomyopathy.

\section{Pathology}

The hearts in chronic Chagas' cardiomyopathy are also overweight (average weight $\mathbf{4 4 5} \mathrm{g}$ ) and dilatation as well as hypertrophy of all cardiac chambers is usually found. The most characteristic lesion is thinning of the left ventricular wall. This may vary in distribution. In $74 \%$ of cases thinning of the left ventricular wall was found in the apical region (Suárez, 1967, 1975), and in $47 \%$ it was aneurysmal with or without thrombosis (Fig. 1). In the other cases it was similar in appearance to those found in ischaemic scars. Thinning of the posterior wall beneath the mitral valve is found less frequently $(22 \%)$. Intracavity thrombosis was particularly prominent in the left ventricle, especially when the apical region showed aneurysmal dilatation, but was also found in the right atrium and atrial appendage. Embolic phenomena of the illness occur more frequently than do systemic emboli.

Histologically, varying degrees of fibrosis are found and not infrequently a chronic inflammatory reaction is also seen. Myocytolysis was observed in 34 cases. Granulomatous lesions with or without giant cells are seldom found. The pseudocysts containing the organism were found in $13 \%$ of the present series, often only one for each heart. When present the parasites are usually in the perinuclear areas, inciting an inflammatory reaction (Fig. 2). Occasionally, increases in arterioles may occur accompanied by an arteritis (Fig. 3). Lesions in the nerve and autonomic ganglion are, in the authors' opinion, secondary and of little importance in the pathogenesis of Chagas' cardiomyopathy (Suárez, 1967).

\section{Acute Chagas' disease}

The myocarditis encountered is often intense and in the interstitium, lymphocytes, histiocytes, plasma cells and neutrophils abound. Parasitic pseudocysts are frequent (Fig. 4) and cardiac necrosis may be present to varying degrees.

\section{References}

Boccalandro, I. \& Hirschhaut, E. (1974) Hemibloqueos y zonas inactivables. Estudio electro y vectocardiográfico. Resúmenes 'VII Congreso Mundial de Cardiologia'. Enfermedad de Chagas y otras Miocardiopatias. 38, 383. Buenos Aires.

Hernández-Pieretti, O,. Gorrín Acosta, M., GallardoColina, E. Pérez-Díaz, J.F., Urbina-Quintana, A.ס Plaja, J., Hernández, M.I. de \& Morales-Briceño, E. (1975) La ecocardiografía aplicada al diagnóstico de las miocardiopatías. Signos ecocardiográficos de la mio cardiopatía chagásica. Archivos Venezolanos de Cardio logia, 2, 105.

HiRSChHAUT, E. (1967) Capacidad Funcional y la Rehabili tación del Cardiópata. Tesis. Universidad Central de Venezuela, Caracas.

HirschHAUT, E. (1972) Capacidad Funcional y la Rehabilitación del Cardiópata. Facultad de Medicina, Universidad Central de Venezuela, Caracas.

Hirschhaut, E., Aparicio, J.M. \& Beer, N. (1975) Estudio sobre la capacidad de trabajo y electrocardiograma de esfuerzo en lamiocardiopatía chagásica. Archivos Venezolanos de Cardiología, 2, 13.

Joyner, C.R. (1974) Ultrasound in the Diagnosis of Cardiovascular-Pulmonary Disease. Year Book Medical Publishers, Inc., Chicago.

Laranja, F.S., Dias, E., Nobrega, G. \& Miranda, A. (1956) Chagas' disease. A clinical, epidemiologic and pathologic study. Circulation, 14, 1035.

Migone, C. (1958) Algunos aspectos de anatomía patologica de cardite chagásica crónica. Tese da Faculdade de Medicina da Universidade de São Paulo.

Pifano, C.F., Romero, J. \& Dominguez, A. (1965) Morfogénesis de las lesiones tempranas producidas por el Schizotrypanum cruzi en condiciones experimentales y sus correlaciones con la infección humana. Archivos Venezolanos de Medicina Tropical y Parasitología Médica, 5, 95.

Pileggi, F., Ebaid, M. \& Tranchesi, J. (1961) El vectorcardiograma en la miocardiopatía chagásica crónica. Cardiología. Instituto Nacional de Cardiología. Editorial Interamericana, S.A., México.

Puigbó, J.J. (1968) Chagas' heart disease. Clinical aspects. Cardiología, 52, 91.

Puigbó, J.J., NaVa-Rhode, J.R., García Barrios, H., SuÁrez, J.A. \& Gil YéPEz, C. (1966) Clinical and epidemiological study of chronic heart involvement in Chagas' disease. Bulletin of the World Health Organization, 34, 655. 
Puigbó, J.J., Nava-Rhode, J.R., Garcia Barrios, H., SuÁrez, J.A., Valero, J.A. \& Valecillos, R.I. (1968) Clasificación evolutiva de la miocardiopatía chagásica crónica. Acta medica venezolana, 15, 331.

Puigbó, J.J., Pisani, F., Boccalandro, I., Blanco, P., Machado, I. \& Valero, J.A. (1968) Estudio de la cardiopatía chagásica crónica. Empleo de la cineangiocardiografía. Acta medica venezolana, 15, 339.

Rosenbaum, M.B., Elizari, M.V. \& Lazzari, J.O. (1968) Los Hemibloqueos p. 203. Editorial Paidos, Buenos Aires.
SuÁrez, C. (1975) Parasitismo de la Fibra Cardiaca en la Miocarditis Chagásica Crónica. Tesis. Universidad Central de Venezuela, Caracas.

SUÁREZ, J.A. (1967) Los Ganglios Neurovegativos Intracardiacos en la Patogenia de la Miocarditis Chagásica. Tesis. Universidad Central de Venezuela, Caracas.

Zoneraich, S. (1974) Non-invasive Methods in Cardiology, p. 337. Charles C. Thomas, Springfield, Illinois. 